\title{
MILK OUTBREAKS OF TICK-BORNE ENCEPHALITIS IN SLOVAKIA, 2012-2016
}

\author{
Erik Dorko', Ján Hockicko², Kvetoslava Rimárová', Andrea Bušová1, Peter Popad'ák ${ }^{3}$, Jana Popad'áková4, Ivan \\ Schréter ${ }^{2}$ \\ ${ }^{1}$ Department of Public Health and Hygiene, Faculty of Medicine, Pavol Jozef Šafárik University in Košice, Košice, Slovak Republic \\ 2Department of Infectology and Travel Medicine, Faculty of Medicine, Pavol Jozef Šafárik University in Košice and Louis Pasteur University \\ Hospital, Košice, Slovak Republic \\ ${ }^{3}$ Department of Forensic Medicine and Pathological Anatomy, Health Care Surveillance Authority, Košice, Slovak Republic \\ ${ }^{4}$ Department of Neurology, Hospital Vranov nad Toplou, Vranov nad Toplou, Slovak Republic
}

\section{SUMMARY}

Objective: Tick-borne encephalitis virus (TBEV) is most commonly transmitted to humans via the bite of an infected tick. Alimentary infection through the consumption of TBEV-contaminated dairy products is also well-documented and is responsible for some diseases in endemic areas. The aim of the study was to emphasize the risk of contracting tick-borne encephalitis (TBE) by consuming raw milk and dairy products and to describe TBE epidemics in Slovakia for the period 2012-2016.

Methods: The data on epidemics were obtained from the Annual Reports for the period 2012-2016 available on the website of the Public Health Authority of the Slovak Republic. Medical records of patients hospitalized during epidemics were provided by the Department of Infectology and Travel Medicine, Faculty of Medicine, Pavol Jozef Šafárik University in Košice, and the Louis Pasteur University Hospital in Košice.

Results: During the period 2012-2016, 13 smaller or larger TBE epidemic outbreaks were recorded in the Slovak Republic. The two outbreaks of TBE reported in 2012 were associated with the consumption of raw goat's milk and dairy products. The first case was an outbreak involving 12 infected people in the Lučenec District. The second case was a family outbreak in the Žilina District, where 3 persons out of 4 family members were infected. In 2013, one epidemic was reported involving 5 persons following the consumption of sheep's cheese from a farm in the Prešov District. One outbreak with 11 cases was reported in 2014. The investigation confirmed its association with the consumption of sheep's cheese in a restaurant located in the Ružomberok District. In 2015, 4 epidemics were described related to the consumption of goat's/ sheep's milk and cheese (Žilina District, Krupina District, Kysucké Nové Mesto District, Trenčín District). In 2016, there were 5 TBE epidemics related to the consumption of milk and dairy products. The largest TBE epidemic outbreak in the last 5 years occurred in the Košice District. In this outbreak approximately 500 people were exposed, and 44 contracted the disease. Infected persons confirmed consumption of sheep's cheese from a farm.

Conclusions: Consumption of milk and dairy products made only from pasteurized milk, as well as the immunization of humans and animals are the most effective preventive measures against TBE.

Key words: tick-borne encephalitis, alimentary infection, outbreaks, cheese, milk, animals

Address for correspondence: E. Dorko, Department of Public Health and Hygiene, Faculty of Medicine, Pavol Jozef Šafárik University in Košice, Šrobárova 2, 04180 Košice, Slovak Republic. E-mail: erik.dorko@upjs.sk

https://doi.org/10.21101/cejph.a5272

\section{INTRODUCTION}

Most tick-borne encephalitis virus (TBEV) infections result from tick bites acquired during outdoor activities in forested areas, although approximately one-third of confirmed TBE cases may not recall any tick exposure preceding their illness (1).

The virus can also be transmitted by consumption of unpasteurized milk or dairy products from viremic livestock (goats, sheep and cows) $(2,3)$. Alimentary infection through the consumption of TBEV-contaminated dairy products is also well-documented and is responsible for some disease outbreaks in endemic areas (4). Countries most often reporting alimentary transmission include Austria (5), the Czech Republic (6), Poland (7), Hungary (8), Slovakia (9), Slovenia (10) and others.
Alimentary-transmitted disease, historically called biphasic milk fever, begins after a shorter incubation period ( $2-4$ days) than that seen from a tick bite (a median of 8 days, range 4-28 days) $(10,11)$.

The first reported milk-borne TBE epidemic in Slovakia occurred in Rožňava in 1951, when more than 600 people were infected, 274 of whom were hospitalized after consuming unpasteurized contaminated milk from the local dairy. Clinical data on patients with milk-borne TBE during the Slovak epidemic outbreak are well documented. Approximately $50 \%$ of the cases exhibited the monophasic form of the disease. In this case, the symptoms included intracranial hypertension, sharp headache, nausea, vomiting, weakness, loss of appetite, dizziness, drowsiness, gastrointestinal problems, epistaxis, pharyngitis, laryngitis and photophobia. The body temperature was about $38.5^{\circ} \mathrm{C}$. The rest of the patients de- 
veloped biphasic disease with a more serious course. There were disturbances of vision, blurred vision or diplopia, and a temperature of up to $40.0^{\circ} \mathrm{C}$ during the first phase, which lasted for approximately 7 days. Following approximately 8 days of remission, the second phase emerged. Problems appeared with the signs of meningeal irritation and/or encephalitis. In general, the course of the disease in the second phase was usually benign. In mild cases, it lasted 3-4 days, in more serious cases 14-21 days. However, encephalitic symptoms, like extrapyramidal, vegetative and nuclear lesions persisted longer, in some cases for more than 5 months (12).

The aim of this paper was to emphasize the risk of acquiring TBE by the consumption of raw milk and dairy products.

\section{MATERIALS AND METHODS}

The data were obtained from the Annual Reports for the period 2012-2016 available on the websites of the Public Health Authority of the Slovak Republic (13).

Medical records of patients hospitalized during the epidemic from the vicinity of the city of Košice were provided by the Department of Infectology and Travel Medicine, Faculty of Medicine, Pavol Jozef Šafárik University in Košice and the Louis Pasteur University Hospital in Košice.

\section{RESULTS}

In the past 5 years 13 milk-borne TBE epidemics/outbreaks have been recorded. A total number of $107(1.98 / 100,000)$ human TBE cases were confirmed and reported in Slovakia in 2012 (as diagnosis A84 tick-borne viral encephalitis in the IDC-10 classification). The European subtype (A84.1 Central European tick-borne encephalitis) was reported in 102 cases $(1.89 / 100,000)$. Five cases $(0.09 / 100,000)$ were reported as unspecified tick-borne viral encephalitis (A84.9). The epidemiological history of patients reported ingestion of unpasteurized milk in 18 cases. Two outbreaks of TBE reported in 2012 were associated with raw goat's milk and dairy products consumption. In the first case, the outbreak involved 12 infected people in the Lučenec District. The second case was a family outbreak in the Žilina District, where 3 persons out of 4 family members were infected. TBE was serologically confirmed using the ELISA test with a positive expression of IgM antibodies.

In 2013, a total of 163 cases were documented (3.01/100,000), 162 of which were classified as A84.1 (2.99/100,000). In 11 cases, ingestion of unpasteurized milk and products made from it was reported. One epidemic was reported. This was a TBE epidemic involving 5 people following the consumption of sheep's cheese from a sheep farm in the village of Proč (Prešov District). Fife of 15 exposed people contracted the disease. Hospitalization was required in all 5 cases. Clinical results showed a body temperature of $38.1-40.0^{\circ} \mathrm{C}$, severe headaches, malaise, loss of appetite, overall weakness, nausea and vomiting. The ill were not vaccinated against TBE. In all 5 cases the disease was confirmed clinically and serologically (IgM). Examination of sheep showed negative results.

In 2014, 116 illnesses $(2.14 / 100,000)$ were classified as A84.1. In the epidemiological history the consumption of raw milk and dairy products was reported by 22 people, and 1 epidemic with 11 cases was reported. The examination showed an association with the consumption of sheep's cheese in a restaurant in the Ružomberok District. The restaurant produced cheese from sheep's milk imported from multiple sites. One milk sample from the Banská Bystrica District tested positive. The animals were not serologically tested.

Central European tick-borne encephalitis was detected 84 times $(1.55 / 100,000)$ in 2015 , and 4 epidemics related to the consumption of goat's/sheep's milk and cheese were described:

- Višňové (Žilina District) - 15 exposed, 7 ill; serological test of 3 goat blood samples showed antibodies against TBEV.

- Krnišov (Krupina District) - 5 exposed, 3 ill; no samples from animals were tested.

- Lopušné Pažitie (Kysucké Nové Mesto District) - 2 exposed, 2 ill; no samples from animals were tested.

- Dolná Poruba (Trenčín District) - 2 exposed, 2 ill; samples from animals were not taken. The death of a 47-year-old man was reported. History confirmed a tick bite and the consumption of raw, unpasteurized goat's milk. IgM antibodies were detected in serum as well as in cerebrospinal fluid (CSF). He was not vaccinated against TBE.

In 2016, there were 5 TBE epidemics related to the consumption of milk and dairy products (the total number of A84.1 cases -173). Three epidemics were of a family character. In two cases (Detva, and Zvolen Districts), goat's milk cheese (14 cases) was the source of infection, while in the Detva District ( 2 cases) cow's milk cheese was the likely source of the epidemic.

The source of the fourth epidemic in 2016 was the consumption of sheep's milk cheese from a farm in the Banská Bystrica District (Selce); in this case 121 people were exposed, and 5 contracted the disease.

The fifth and the largest TBE epidemic in the last 5 years is the one in Košice. According to the 2016 Annual Report of the Public Health Authority of the Slovak Republic, approximately 500 people were exposed and 44 contracted the disease. Those confirmed consumption of sheep's cheese purchased in late April and early May in a shop in Nižný Klatov, Košice District. In 43 patients the disease was confirmed by serological examination for specific IgM and IgG antibodies in serum, in 12 patients also in CSF.

Between 24 May 2016 and 20 June 2016, 36 patients (20 women and 16 men) were hospitalised at the Department of Infectology and Travel Medicine, with an average length of hospitalization 6.9 days (4-12 days), with an average incubation period of 13.8 days ( 4 days -4 weeks). Laboratory results showed the presence of leucocytosis and higher levels of CRP. Body temperature increased up to $40.0{ }^{\circ} \mathrm{C}(100.0 \%, \mathrm{n}=36)$, and headaches $(100.0 \%, \mathrm{n}=36)$, weakness in limbs $(86.1 \%, \mathrm{n}=31)$, gait disturbance $(52.7 \%, \mathrm{n}=19)$, meningeal signs $(50.0 \%$, $\mathrm{n}=18$ ) were among the most common clinical symptoms. Less frequent symptoms included abdominal pain $(47.2 \%, \mathrm{n}=17)$, vomiting $(36.2 \%, \mathrm{n}=13)$, limb tremors $(36.2 \%, \mathrm{n}=13)$, confusion $(16.6 \%, \mathrm{n}=6)$ and photophobia $(16.6 \%, \mathrm{n}=6)$. Very rare symptoms included diplopia, neurasthenia, vertigo, fatigue syndrome, lower limbs paraparesis, cough, tetany, paraesthesia, cerebral syndrome, and insomnia. Symptomatic treatment, which included analgesics, anti-oedema treatment (mannitol, corticoids), infusion rehydration treatment and group B and $\mathrm{C}$ vitamins, was applied to patients. Data on the epidemics can be found in Table 1 . 
Table 1. Milk outbreaks of TBE in Slovakia, 2012-2016 (13)

\begin{tabular}{|l|c|c|c|}
\hline Location district/county & Duration & Number of ill/exposed & Source \\
\hline Lučenec/Budiná & 1 to 19 June 2012 & $12 / 12$ & goat's milk, cheese \\
\hline Žilina/Lietava & 18 May to 5 June 2012 & $3 / 4$ & goat's milk, cheese \\
\hline Prešov/Proč & 1 to 23 July 2013 & $5 / 15$ & sheep's milk cheese \\
\hline Ružomberok & 4 April to 4 May 2014 & $11 / 21$ & sheep's milk cheese \\
\hline Žilina/Višňové & 20 May to 30 August 2015 & $7 / 15$ & goat's milk \\
\hline Krupina/Krnišov & 31 July to 7 September 2015 & $3 / 5$ & sheep's milk, cheese \\
\hline Kysucké Nové Mesto/Lopušné Pažitie & 20 June to 30 November 2015 & $2 / 2$ & goat's milk \\
\hline Trenčín/Dolná Poruba & 29 June to 1 July 2015 & $2 / 2$ & sheep's milk cheese \\
\hline Košice/Nižný Klatov & 10 to 29 May 2016 & $44 / 500$ & sheep's milk cheese \\
\hline Banská Bystrica/Selce & 16 to 26 May 2016 & $5 / 121$ & goat's milk cheese \\
\hline Detva 1 & 30 May to 11 June 2016 & $4 / 4$ & cow's milk cheese \\
\hline Detva 2 & 20 to 21 October 2016 & $2 / 2$ & goat's milk cheese \\
\hline Zvolen & 5 to 17 November 2016 & $10 / 11$ &
\end{tabular}

\section{DISCUSSION}

Approximately $1 \%$ of all TBEV infections in humans is probably acquired by consuming infected unpasteurized milk or dairy products from infected livestock (11). The risk of TBE transmission by unpasteurized milk is associated with the current trend of the Ixodes ricinus tick spreading from foothills and mountainous areas into higher altitudes as a result of global warming (6).

Based on the results of the epidemiological investigation, in the majority of cases TBE virus was transmitted by raw (unpasteurized) goat's milk/cheese $(6,8,10,14,15)$. The question is whether the goats have more intense viraemia, longer lasting viraemia or merely goat's milk/cheese is more often consumed raw due to the belief that it is "healthier" this way (14). Fewer authors have reported the occurrence of TBEV in milk and/or cheese from sheep and cows $(6-8,10)$.

In our study, sheep's milk cheese was the most common cause of infection. According to data obtained from the Central Registry of Livestock website, currently 389,094 sheep compared to 18,266 goats are registered in Slovakia (as of 2 October 2017, Breeding services SK, 2017) (16). As the number of sheep exceeds the number of goats by more than 20 times, there is a prerequisite for more frequent consumption of sheep's cheese and therefore a greater risk of infection (if sheep are infected).

Many authors indicate in their works the transmission of TBE by food $(5,6,8,10,14,15)$. Kríz et al. between 1997 and 2008 recorded 64 cases of TBE in patients who reported consumption of unpasteurized goat's milk (36 patients, $56.3 \%$ ) or cheese from unpasteurized sheep's milk (21 patients, 32.8\%). Cow's milk-borne infection was responsible for the remaining $7 \mathrm{TBE}$ cases $(10.9 \%)(6)$.

In Hungary, Caini et al. probably recorded the first report in the EU on the outbreak of TBE allegedly due to unpasteurised cow's milk (8). The potential of infectious diseases spreading by drinking unpasteurised cow's milk is well known. Due to the regular consumption of cow's milk, demonstrating the presence of TBEV in over 10 percent of raw cow's milk samples is of particular epidemiological significance (7). Cow's milk is far more frequently consumed than goat's and sheep's milk, and because the habit of buying milk from small farmers (that may not fulfil all the requirements for milk safety) is not rare, especially in the countryside, the implication of unpasteurised cow's milk consumption as the cause of TBE outbreaks should not be overlooked (8).

The stability of TBEV in milk depends on storage conditions. The virus was stable in milk maintained under cold conditions; however, there was a marked reduction in virus titre after incubation at room temperature. High temperature and short-term pasteurization protocols completely inactivated the virus (4).

The pasteurization method called "high temperature, short time" (HTST) is one of the most common ways of commercial pasteurization of milk for consumption (17). HTST pasteurization specifies that milk is to be heated to $72{ }^{\circ} \mathrm{C}$ for 15 seconds, and then immediately cooled to refrigeration temperature $\left(4^{\circ} \mathrm{C}\right)$. No virus was detected following this treatment, which indicates that pasteurization should be effective in inactivating TBEV (4).

With the increasing popularity of raw milk consumption, there is potential for an increase in the number of cases of alimentary TBEV in endemic areas (4). Milk is often consumed raw among farm families because of taste and convenience. There is also a small portion of the general population which drinks raw milk because it is believed to be able to prevent and treat certain diseases (18). The sale of unpasteurized products is allowed in some countries. Some consumers believe that raw milk tastes better or is more nutritious than pasteurized milk. More recently, in parts of Europe and Russia, raw milk vending machines have become available, so that the public can purchase local, unprocessed dairy products (17).

Decree No. 343/2016 of the Ministry of Agriculture and Rural Development of the Slovak Republic also states the requirements for heat treatment of milk, cream and cheese products from cow's, sheep's and goat's milk, which are rather recommendations and not strict regulations (19). Should consumers insist on drinking unboiled milk, another option would be immunization of livestock in TBEV-endemic areas, because results show that milk from immunized animals is not infectious (18). However, no vaccines against TBEV for animals are available. Vaccination is merely optional - even for humans.

In Europe, there are currently two vaccines licensed for human use, with special formulations or vaccination schemes for children and adults. Neither of the two pharmaceutical companies producing them (Novartis and Baxter) has their TBE vaccines licensed for animal use. Vaccines from both companies have been successfully 
used to vaccinate various animal species (e.g. sheep, goats, roe deer, dogs) without any adverse effect (20).

The risk of TBEV infection through milk consumption was assessed hitherto by serological examinations of animals suspected to be a source of milk-borne infections in humans. The greatest occurrence of TBE virus was found in sheep's milk (22.2\%), followed by goat's milk (20.7\%) and cow's milk (11.1\%). Based on the ELISA test, the greatest prevalence of anti-TBEV antibodies was also found in sheep's milk (14.8\%), followed by cow's milk (3.2\%) and goat's milk (0\%) (7). Specific antibodies persist in sheep and goats for at least 28 months after experimental infection $(21,22)$. In case of cattle, specific antibodies persist for at least 14 weeks after immunization. TBEV antibodies in animals might serve as a tool for clinical veterinary diagnostics as well as for describing a natural TBEV focus (23).

The consumption of raw goat's, sheep's and cow's milk may be associated with risk of infection with TBEV. Therefore, pasteurization of milk before consumption is strongly recommended, especially in locations where grazing goats, sheep and cows are exposed to tick bite. Hence, vaccination of animals should be considered as an effective preventive measure in highly endemic areas.

\section{CONCLUSIONS}

The increasingly fashionable natural lifestyle encourages consumption of raw milk and products made from unpasteurized milk. Even though alimentary transmission of TBEV is rare, the risk of such exposures could be reduced through education campaigns that encourage people to consume only milk that has been boiled or pasteurized, and only dairy products made from pasteurized milk (10).

In addition, TBE transmission by unpasteurised milk could be effectively prevented by vaccinating people and/or milk-producing animals. Therefore, public health services should primarily focus their efforts towards prohibiting the sale of milk by farmers without authorisation and informing the public about the risks associated with consumption of unpasteurised milk and the beneficial effects of boiling such milk before drinking or processing (8).

There is a lack of systematic surveillance of foodborne viral diseases, including TBE, which results in underreporting. Adjustments in local and regional policies should be made to consider shifting trends of food origin, preparation and distribution. Better coordination between veterinary and public health sectors should result in a prompt action of recognizing every emergence of foodborne infection and, consequently, reducing the burden of the disease in the population (14).

\section{Acknowledgements}

This work was supported by VEGA grants no. 1/0198/13 and 1/0011/14 of the Ministry of Education, Science, Research and Sport of the Slovak Republic.

\section{Conflict of Interests}

None declared

\section{REFERENCES}

1. World Health Organization. Vaccines against tick-borne encephalitis: WHO position paper. Wkly Epidemiol Rec. 2011 Jun;86(24):241-56.
2. Amicizia D, Domnich A, Panatto D, Lai PL, Cristina ML, Avio U, et al. Epidemiology of tick-borne encephalitis (TBE) in Europe and its prevention by available vaccines. Hum Vaccin Immunother. 2013 May;9(5):1163-71.

3. Petri E, Gniel D, Zent O. Tick-borne encephalitis (TBE) trends in epidemiology and current and future management. Travel Med Infect Dis. 2010 Jul;8(4):233-45.

4. Offerdahl DK, Clancy NG, Bloom ME. Stability of a tick-borne Flavivirus in milk. Front Bioeng Biotechnol. 2016 May;4:40. doi: 10.3389/ fbioe.2016.00040.

5. Holzmann H, Aberle SW, Stiasny K, Werner P, Mischak A, Zainer B, et al. Tick-borne encephalitis from eating goat cheese in a mountain region of Austria. Emerg Infect Dis. 2009 Oct;15(10):1671-3.

6. Křǐž B, Beneš C, Daniel M. Alimentary transmission of tick-borne encephalitis in the Czech Republic (1997-2008). Epidemiol Mikrobiol Imunol. 2009 Apr;58(2):98-103.

7. Cisak E, Wójcik-Fatla A, Zając V, Sroka J, Buczek A, Dutkiewicz J. Prevalence of tick-borne encephalitis virus (TBEV) in samples of raw milk taken randomly from cows, goats and sheep in eastern Poland. Ann Agric Environ Med. 2010;17(2):283-6.

8. Caini S, Szomor K, Ferenczi E, Székelyné Gáspár Á, Csohán Á, Krisztalovics K, et al. Tick-borne encephalitis transmitted by unpasteurised cow milk in western Hungary, September to October 2011. Euro Surveill. 2012 Mar;17(12). pii=20128.

9. Labuda M, Eleckova E, Lickova M, Sabo A. Tick-borne encephalitis virus foci in Slovakia. Int J Med Microbiol. 2002 Jun;291 Suppl 33:43-7.

10. Hudopisk N, Korva M, Janet E, Simetinger M, Grgič-Vitek M, Gubenšek $\mathrm{J}$, et al. Tick-borne encephalitis associated with consumption of raw goat milk, Slovenia, 2012. Emerg Infect Dis. 2013 May;19(5):806-8.

11. Bogovic P, Strle F. Tick-borne encephalitis: a review of epidemiology, clinical characteristics, and management. World J Clin Cases. 2015 May;3(5):430-41.

12. Růžek D, Dobler G, Mantke OD. Tick-borne encephalitis: pathogenesis and clinical implications. Travel Med Infect Dis. 2010 Jul;8(4):223-32.

13. Public Health Authority of the Slovak Republic. Annual report [Internet]. Bratislava: Public Health Authority of the Slovak Republic; c2009 [cited 2017 Sep 13]. Available from: ttp://www.uvzsr.sk/index.php?option=com content\&view=category\&layout=blog\&id=25\&Itemid=34 (In Slovak.)

14. Markovinovic L, Kosanovic Ličina ML, Tešic V, Vojvodic D, Vladušic Lucic I, Kniewald T, et al. An outbreak of tick-borne encephalitis associated with raw goat milk and cheese consumption, Croatia, 2015. Infection. 2016 Oct;44(5):661-5.

15. Kerbo N, Donchenko I, Kutsar K, Vasilenko V. Tickborne encephalitis outbreak in Estonia linked to raw goat milk, May-June 2005. Euro Surveill. 2005 Jun;10(25). pii $=2730$.

16. Breeding services of the Slovak Republic. Central register of livestock [Internet]. Bratislava: Breeding services of the Slovak Republic; 2010 [cited 2017 Oct 3]. Available from: https://www.cehz.sk/index.jsp. (In Slovak.)

17. International Dairy Foods Association. Pasteurization [Internet]. Washington: International Dairy Foods Association; 2017 [cited 2017 Oct 3]. Available from: https://www.idfa.org/news-views/media-kits/milk/ pasteurization.

18. Balogh Z, Egyed L, Ferenczi E, Bán E, Szomor KN, Takács M, et al. Experimental infection of goats with tick-borne encephalitis virus and the possibilities to prevent virus transmission by raw goat milk. Intervirology. 2012;55(3):194-200.

19. Decree No. 343 of Ministry of Agriculture and Rural Development of the Slovak Republic of December 8, 2016, which defines details on some dairy products. Zbierka zákonov SR. 2016;Pt 112. (In Slovak.)

20. Pfeffer M, Dobler G. Tick-borne encephalitis virus in dogs - is this an issue? Parasit Vectors. 2011 Apr;4:59. doi: 10.1186/1756-3305-4-59.

21. Klaus C, Hoffmann B, Moog U, Schau U, Beer M, Süss J. Can goats be used as sentinels for tick-borne encephalitis (TBE) in non-endemic areas? Experimental studies and epizootiological observations. Berl Munch Tierarztl Wochenschr. 2010 Nov-Dec;123(11-12):441-5.

22. Klaus C, Ziegler U, Kalthoff D, Hoffmann B, Beer M. Tick-borne encephalitis virus (TBEV) - findings on cross reactivity and longevity of TBEV antibodies in animal sera. BMC Vet Res. 2014 Apr;10:78. doi: 10.1186/1746-6148-10-78.

23. Klaus C, Beer M, Saier R, Schubert H, Bischoff S, Süss J. Evaluation of serological tests for detecting tick-borne encephalitis virus (TBEV) antibodies in animals. Berl Munch Tierarztl Wochenschr. 2011 NovDec;124(11-12):443-9. 